\title{
ANALISIS PENGAKUAN PENDAPATAN BUNGA ATAS PEMBERIAN KREDIT MODAL KERJA PADA PT. BANK PERKREDITAN RAKYAT PRISMADANA
}

\author{
Timothy Ray Korah ${ }^{1}$ \\ David Paul Elia Saerang ${ }^{2}$ \\ Heince Wokas ${ }^{3}$
}

Fakultas Ekonomi Jurusan Akuntansi

Universitas Sam Ratulangi Manado

Email: timothykorah@gmail.com

\begin{abstract}
The largest bank revenue is interest income from credit. In general, bank lending business and one of the most interest product.Therefore the recognition and measurement of the right to credit interest income must be relevant, accurate, and accounted for, so the financial statements truly on the real financial position. The research aims to determine how the accounting treatment of the recognition of interest income on PT.BPR PRISMA DANA is already in appropriate with the applicable accounting standards, The method used in this research is descriptive analysis method. The results of research conducted in PT.BPR PRISMA DANA, showed recognition of loan interest income using the accrual basis or more leads to the realization of the concept.Except for interest income on loans classified as problematic (nonperforming) is recognized when it is received (cash basis). Interest income using the effective interest annuity system is calculated based on the remaining principal.
\end{abstract}

Keywords: Revenue/income, Recognition of interest income, Accrual basis

\section{PENDAHULUAN}

Dalam UU No.10 tahun 1998 tentang perbankan pada bab1 pasal1 menyatakan bahwa, yang dimaksud dengan bank adalah badan usaha yang menghimpun dana dari masayarakat dalam bentuk simpanan dan menyalurkan kepada masyarakat dalam rangka meningkatkan taraf hidup rakyat banyak. Untuk itu bank sebagai lembaga kepercayaan masyarakat harus mampu membantu masyarakat dalam memberikan pelayanan, dalam hal ini nasabah bank itu sendiri. Bank merupakan lembaga keuangan yang fungsi utamanya adalah menghimpun dana dari masyarakat, menyalurkan dana kepada masyarakat, dan juga memberikan pelayanan dalam bentuk jasajasa pelayanan (Ismail 2009:12).

Dalam operasional suatu bank, pendapatan adalah salah satu elemen dasar yang mempengaruhi penyajian laporan rugi/laba. Dimana pengakuan dan pengukuran yang benar terhadap pendapatan secara langsung berpengaruh terhadap pengakuan dan pelaporan laba. Dimana jika terjadi kesalahan penyajian pendapatan akan megakibatkan penyajian laporan keuangan perusahaan tidak menggambarkan posisi keuangan yang sesungguhnya. Pendapatan dapat dianggap sebagai kompensasi dari penjualan produk perusahaan (barang dan jasa), dan dapat diukur dalam satuan moneter dalam hal ini jumlah rupiah. Dimana laba timbul sebagai akibat dari jumlah pendapatan melebihi total biaya yang dibebankan atas produk yang dijual.

Menurut Ikatan Akuntansi Indonesia dalam Pedoman Standar Akuntansi keuangan (PSAK Tahun 2010 No.23) menyatakan bahwa: pendapatan adalah penghasilan yang timbul selama dalam aktivitas normal entitas dan dikenal dengan bermacam-macam sebutan yang berbeda seperti penjualan, penghasilan jasa (fees), bunga, dividen dan royalti.

Permasalahan akuntansi dalam akuntansi khususnya pendapatan adalah saat pengakuan pendapatan atas transaksi yang terjadi. Pendapatan diakui bila besar kemungkinan manfaat ekonomi masa depan akan mengalir ke bank dan manfaat ini dapat diukur dengan andal. Pada hakekatnya, pendapatan merupakan arus masuk sumber daya yang berasal dari kegiatan-kegiatan usaha bank yang biasanya diakibatkan oleh penyelesaian transaksi pertukaran produk ekonomi. Maksudnya jika bank menjual atau memberikan produk-produknya kepada pihak lain (nasabah), maka otomatis bank menerima pendapatan. 
Menurut jenis penggunaannya kredit dapat dibedakan menjadi kredit usaha dan kredit konsumsi. Kredit usaha adalah kredit yang digunakan untuk pembiayaan dalam bentuk modal kerja atau investasi. Kredit konsumsi merupakan kredit yang dipergunakan untuk kebutuhan sendiri bersama keluarganya, seperti kredit rumah atau mobil yang akan digunakan sendiri bersama keluarganya (Malayu Hasibuan 2011 : 89).

Dalam penelitian yang akan dibahas lebih lanjut adalah kredit modal kerja yang merupakan bagian dari kredit usaha. Kredit modal kerja merupakan kredit yang digunakan untuk keperluan untuk meningkatkan produksi dalam operasionalnya. Sebagai contoh kredit modal kerja diberikan untul membeli bahan baku, membayar gaji pegawai atau biaya-biaya kliennya yang berkaitan dengan proses produksi perusahaan (Kasmir 2011 : 109).

Berdasarkan latar belakang di atas, maka penulis mendapat ide untuk melakukan penelitian pada Bank Perkreditan Rakyat Prisma Dana dengan judul: "Analisis Pengakuan Pendapatan Bunga Atas Pemberian Modal Kerja Pada PT. Bank Perkreditan Rakyat Prisma Dana Manado".

\section{TINJAUAN PUSTAKA \\ Konsep Akuntansi}

Akuntansi adalah suatu sistem informasi yang mengidentifikasikan, mencatat, dan mengkomunikasikan kejadian ekonomi dari suatu organisasi kepada pihak yang berkepentingan (menurut Weygandt dalam Yadiati dan Wahyudi 2006: 7-8).

Horngren (2007: 4) memberikan pengertian akuntansi is the information system that measures business activities, process that information into reports communicates the result to decision makers. Atau dengan kata lain, akuntansi adalah system yang mengukur aktivitas bisnis, proses mengenai informasi untuk menghasilkan laporan dan mengkomunikasikan hasil kepada pembuat keputusan.

Definisi lain dapat juga dipakai untuk memahami lebih dalam pengertian akuntansi ini. Dalam buku $A$ Statement of Basic Accounting Theory (ASOBAT), akuntansi diartikan sebagai berikut: "Proses mengidentifikasikan, mengukur dan menyampaikan informasi ekonomi sebagai bahan dalam mempertimbangkan berbagai alternatif dalam mengambil kesimpulan oleh para pemakainya".

Komite istilah American Institute of Certified Public Accounting (AICPA) mendefinisikan akuntansi sebagai berikut: "Akuntansi adalah seni pencatatan, penggolongan, dan pengikhtisaran dengan cara tertentu dan dalam ukuran moneter, transaksi dan kejadian-kejadian yang umumnya bersifat keuangan dan termasuk menafsirkan hasil-hasilnya". Definisi ini bisa dipermasalahkan seandainya kita berhadapan dengan keadaan system pencatatan yang sudah menggunakan komputerisasi, apa lagi proses pengolahan datanya tidal lagi melalui pencatatan, tetapi melalui optic, scanning, dialing, atau keyboard sehingga sama sekali tidak melibatkan proses pencatatan konvensional. Beberapa definisi tersebut sudah out of date. Accounting Principle Board (APB) statement No.4 mendefinisikan akuntansi sebagai berikut: "Akuntansi adalah suatu kegiatan jasa. Fungsinya adalah memberikan informasi kuantitatif, umumnya dalam ukuran uang, mengenai suatu badan ekonomi yang dimaksudkan untuk digunakan dalam pengambilan keputusan ekonomi sebagai dasar memilih di antara beberapa alternatif' (Harahap 2011:5). Akuntansi memiliki kerangka teori konseptual yang menjadi dasar pelaksanaan teknik-tekniknya, kerangka dasar konseptual ini terdiri dari standar (teknik,prinsip) dan praktik yang sudah diterima oleh umum karena kegunaan dan kelogisannya. Standar itu disebut standar akuntansi, di Indonesia kemudian menjadi Standar Akuntansi Keuangan (SAK). Indonesia kemudian menjadi Pernyataan Standar Akuntansi Keuangan (PSAK). SAK merupakan pedoman bagi siapa saja dalam menyusun laporan keuangan yang akan diterima oleh umum (Harahap 2011: 153).

\section{Pengertian Bank}

Bank termasuk kategori perusahaan jas yang bergerak dalam bidang keuangan, yang tugas utamanya sebagai lembaga mediator yaitu menghimpun dana dari masyarakat dalam hal ini nasabah dalam bentuk tabungan dan simpanan lainnya untuk disalurkan kembali kepada masyarakat dalam bentuk pemberian kredit atau menghimpun dana dari pihak surplus dan kemudian menyalurkan dana kepada pihak deficit. Secara sederhana bank diartikan sebagai lembaga keuangan yang kegiatan usahanya adalah menghimpun dana dari masyarakat dan menyalurkan kembali dana tersebut ke masyarakat serta memberikan jasa-jasa lainnya. Sedangkan pengertian lembaga keuangan dimana kegiatannya apakah hanya menghimpun dana atau hanya menyalurkan dana atau kedua-duanya ( Kasmir 2011: 2-3 ).

Pengertian bank menurut Undang-Undang Perbankan Nomor 10 tahun 1998 yang dikutip oleh Ismail (2010: 3) adalah menyalurkannya ke masyarakat dalam bentuk kredit dan/atau bentuk-bentuk lainnya dalam rangka meningkatkan taraf hidup rakyat banyak. Oleh karena itu, penempatan dalam bentuk kredit akan memberikan kontribusi pendapatan bunga kredit bagi bank. 


\section{Akuntansi Perbankan}

Menurut Ismail (2009: 14), Akuntansi bank merupakan seni pencatatan, penggolongan, pengikhtisaran atas seluruh transaksi yang terjadi di dalam bank. Transaksi-transaksi yang dicatat oleh bank meliputi transaksi keuangan maupun transaksi lainnya yang akan mengakibatkan adanya peristiwa keuangan yang akan terjadi di masa yang akan datang. Hasil dari transaksi akuntansi bank berupa laporan keuangan bank. Laporan keuangan bank bertujuan untuk menyediakan informasi yang menyangkut posisi keuangan, kinerja bank, perubahan posisi keuangan, arus kas serta informasi-informasi lainnya yang bermanfaat bagi pengguna laporan keuangan.

\section{Akuntansi Kredit}

Ismail (2010:198) menjelaskan bahwa kredit dicatat dalam neraca pada saat pencairan kredit sebesar jumlah uang yang dikeluarkan oleh bank kepada nasabah. Pada saat bank memberikan persetujuan kredit dan mengirimkan surat persetujuan kredit kepada calon debitur, maka jumlah plafon kredit yang telah disetujui ini dicatat dalam rekening administratif atau pada kewajiban komitmen "fasilitas kredit kepada nasabah yang belum digunakan." Pencatatan akuntansi kredit dimulai pada saat ditandatanganinya perjanjian kredit antara bank dan debitur. Setelah tanda tangan perjanjian kredit, bank harus mencatat dalam kewajiban komitmen. Dalam hal debitur mencairkan kreditnya, maka bank akan mencatat jumlah pencairan kredit ke dalam 'kredit yang diberikan' pada posisi aktiva bank.

Pencatatan akuntansi kredit dimulai pada saat ditandatanganinya perjanjian kredit antara bank dan debitur. Setelah tanda tangan perjanjian kredit, bank harus mencatat dalam kewajiban komitmen. Dalam hal debitut mencairkan kreditnya, maka bank akan mencatat jumlah pencairan kredit ke dalam 'kredit yang diberikan' pada posisi aktiva bank.

Pada saat penandatanganan perjanjian kredit, jurnal yang dibuat yaitu sebagai berikut.

Rek. Lawan-Kewajiban Komitmen XXX

Fasilitas kredit kepada nasabah yang

$\mathrm{XXX}$

belum digunakan

Giro PT X

Provisi diterima di muka

XXX

Giro Notaris

Giro Perusahaan Asuransi

$\mathrm{XXX}$

XXX

XXX

(dalam hal pembayaran biaya-biaya saat perjanjian)

Pada saat pencairan kredit, maka Bank menjurnal balik kewajiban komitmen tersebut, sehingga "Fasilitas Kredit kepada nasabah yang belum digunakan" menjadi nihil. Di samping itu, Bank menjurnal kredit yang diberikan pada sisi aktiva bank, karena dana bank telah disalurkan kepada nasabah dalam bentuk kredit. Jurnal yang dibuat yaitu sebagai berikut.

Kredit yang diberikan

$\mathrm{XXX}$

Tabungan-PT X

$\mathrm{xxx}$

Fasilitas kredit kepada nasabah yang belum digunakan

Rek. Lawan-Kewajiban Komitmen

XXX

XXX

Pada akhir bulan, bank melakukan penyesuaian terhadap provisi diterima di muka dan pengakuan pendapatan bunga pada akhir bulan dengan jurnal sebaagi berikut.

Provisi deterima di muka

Pendapatan provisi

XXX

XXX

Jurnal yang dibuat pada saat penyesuaian pengakuan pendapatan bunga pada akhir bulan yaitu sebagai berikut.

Pendapatan bunga kredit yang akan diterima

Pendapatan bunga kredit

$\mathrm{xxX}$

$\operatorname{XXX}$

\section{Pendapatan}

Pengertian pendapatan menurut IAI (Ikatan Akuntansi Indonesia) dalam (PSAK no.23, 2010: par 6) tentang akuntansi pendapatan pada paragraf 6 menyatakan: "Pendapatan adalah arus masuk bruto dari manfaat ekonomi yang timbul dari aktifitas normal entitas selama suatu periode jika arus masuk itu mengakibatkan kenaikan ekuitas, yang tidal berasal dari kontribus penanam modal.”. 


\section{Pendapatan Bank}

Pendapatan (revenue) adalah arus masuk bruto dari manfaat ekonomi yang timbul dari manfaat ekonomi yang timbul dari aktivitas normal bank selama satu periode yang mengakibatkan kenaikan ekuitas dan tidak secara langsung dari kontribusi penanaman modal, (Moh. Ramly Faud dan M. Rustan D.M, 2005: 281) pendapatan bank pada hakekatnya berasal dari jasa usaha yang dapat dibagi menjadi 3 bidang usaha, yaitu :

1. Penghimpunan dana dari masyarakat berupa giro, tabungan dan deposito.

2. Pemberian kredit jangka pendek, menengah, dan panjang atau turut dalam perusahaan dengan persetujuan dan syarat-syarat yang ditetapkan oleh Bank Indonesia (BI).

3. Pemberian jasa-jasa lainnya seperti Transfer, inkaso, serta safe box dan jaminan bank serta usaha lain yang tidak lazim dilakukan dalam suatu bank umum seperti dana pensiun.

\section{Pengakuan Pendapatan}

Berikut ini tentang beberapa cara pengakuan pendapatan menurut IAI dalam PSAK No. 23 Tahun 2010, sebagai berikut :

1. Pendapatan diakui pada saat penjualan.

Merupakan cara pengakuan pendapatan yang sudah lazim dan telah lama digunakan oleh perusahaanperusahaan. Pendapatan diakui pada saat penjualan apabila :

a. Harga pokok dan biaya-biaya yang timbul sudah dapat dipastikan.

b. Harga jual dapat ditentukan dengan pasti.

c. Barang/jasa telah dilepaskan atau diserahkan oleh penjual.

d. Secara ekonomis nilai jualnya merupakan jumlah kuantitas yang terjual dikalikan harga jualnya, dapat menjadi nilai tambah asset setelah dikurangi harga pokok barang/jasa yang diserahkan.

2. Pendapatan diakui pada saat jasa telah selesai dilakukan

Perusahaan yang bergerak dalam bidang jasa, pendapatan dicatat dan diakui sebagai pendapatan pada saat jasa telah selesai dilakukan atau diserahkan dan dapat dibuat fakturnya.

3. Pendapatan diakui sejalan dengan berlalunya waktu.

Aktiva perusahaan yang digunakan oleh pihak lain akan menghasilkan pendapatan berupa pendapatan sewa royalty atau pendapatan bunga. Pendapatan ini dicatat dan diakui sejalan dengan berlalunya waktu setelah digunakannya aktiva.

\section{Pendapatan Bunga Kredit}

Dalam aktivitas operasionalnya, pendapatan yang diterima bank dari produk kredit salah satunya berbentuk bunga. IAI (PSAK No.23 : 2010) mendefinisikan bunga adalah pembebanan untuk penggunaan kas atau setara dengan kas atau jumlah terutang kepada entitas. Dari pengertian tersebut dapat ditarik satu definisi yaitu, pendapatan bunga kredit adalah pendapatan yang berasal dari pembebanan untuk penggunaan kas atau setara kas atau jumlah terutang kepada bank, yang berbentuk imbalan yang dibayarkan debitur atas kredit yang diterimanya.

\section{Pengertian Kredit Modal Kerja}

Menurut Kasmir (2011:109), kredit modal kerja merupakan kredit yang digunakan untuk keperluan meningkatkan produksi dalam operasionalnya. Sebagai contoh kredit modal kerja diberikan untuk membeli bahan baku, membayar gaji pegawai atau biaya-biaya yang berkaitan dengan proses produksi suatu perusahan.

\section{METODE PENELITIAN}

Dalam melaksanakan penelitian ini, penulis menggunakan metode analisis deskriptif .Analisis Deskriptif adalah suatu metode penelitian yang berusaha mengumpulkan, menyusun serta menyajikan, sehingga hasilhasil penelitian dapat memberikan gambaran yang jelas pada obyek yang teliti. Dengan demikian peneliti melihat secara keseluruhan dan mengamati pengakuan pendapatan bunga pada PT.BPR Prisma Dana Manado serta membandingkan data yang diperoleh dari hasil yang diperoleh dari hasil penelitian dengan Standar Akuntansi Keuangan. 


\section{HASIL PENELITIAN DAN PEMBAHASAN}

\section{Hasil Penelitian}

Kredit yang diberikan oleh bank dapat didefiniskan sebagai penyediaan uang atau tagihan yang dapat dipersamakan dengan itu, berdasarkan persetujuan dan kesepakatan pinjam-meminjam untuk melunasi hutangnya setelah jangka waktu tertentu dengan jumlah bunga, imbalan atau pembagian hasil keuntungan, disamping itu setelah kredit dikucurkan , bank selalu memantau kualitas kredit. Karena semakin lama jangka waktu kredit umumnya semakin besar pula resikonya. Hal-hal ini akan berimplikasi pada pencatatan anggara pokok dan bunga, penyisihan penghapusan hingga penyelamatan kredit.

Komitmen kredit merupakan transaksi off balanced, yaitu transaksi yang belum mempegaruhinya bila komitmen tersebut direalisasikan. Jadi pada saat komitmen kredit dipenuhi atau bank melakukan pengucuran kredit dropping dana, maka komitmen benar-benar efektif. Pada saat realisasi kredit, bank akan memungut beban terhadap debitur yang berarti pendapatan bagi bank. Beban inin bisa berasal dari provisi, biaya administrasi, biaya transaksi jaminan, biaya asuransi, biaya bunga dan sebagainya. Pada Bank Perkreditan Rakyat ini pendapatan terbesar berasal dari aktivitas perkreditan dalam hal ini pendapatan bunga kredit Penulis telah melakukan wawancara dan pengolahan data yang berkaitan dengan pengakuan pendapatan bunga atas pemberian kredit modal kerja oleh PT. BPR Pismadana Manado. Wawancara yang dilakukan menghasilkan data yang dapat dibandingkan dengan pedoman akuntansi Bank Perkreditan Rakyat (PA-BPR) dan Pernyataan Standar Akuntansi Keuangan (PSAK) NO.23 tentang pendapatan.

\section{TABEL 4.1 Jumlah Kredit yang diberikan PT. BPR PRISMA DANA}

\begin{tabular}{|l|c|c|c|}
\hline \multicolumn{1}{|c|}{ KETERANGAN } & $\begin{array}{c}\text { PERIODE } \\
\text { MARET 2013 }\end{array}$ & $\begin{array}{c}\text { PERIODE } \\
\text { DESEMBER 2012 }\end{array}$ & JUNI 2012 \\
\hline Kredit yang diberikan & & & 175.988 .000 \\
\hline $\begin{array}{l}\text { a. Kepada pihak yang } \\
\text { terkait }\end{array}$ & 203.860 .800 & 192.986 .300 & 200.573 .900 \\
\hline $\begin{array}{l}\text { b. Kepada pihak tidak } \\
\text { terkait }\end{array}$ & 212.498 .400 & 209.564 .100 & \\
\hline
\end{tabular}

Komitmen kredit merupakan transaksi off balanced, yaitu transaksi yang belum mempegaruhinya bila komitmen tersebut direalisasikan. Jadi pada saat komitmen kredit dipenuhi atau bank melakukan pengucuran kredit dropping dana, maka komitmen benar-benar efektif. Pada saat realisasi kredit, bank akan memungut beban terhadap debitur yang berarti pendapatan bagi bank. Beban ini bisa berasal dari provisi, biaya administrasi, biaya transaksi jaminan, biaya asuransi, biaya bunga dan sebagainya. Pada Bank Perkreditan Rakyat ini pendapatan terbesar berasal dari aktivitas perkreditan dalam hal ini pendapatan bunga kredit.

\section{Pengakuan Pendapatan Bunga Kredit pada PT.BPR PRISMADANA}

Kredit yang diberikan diakui pada saat pencairan dan dinyatakan sebesar jumlah yang tagihan kepada nasabah. Jurnal yang dibuat PT.Bank Perkreditan Rakyat Prismadana Manado saat pemberian kredit /saat timbulnya biaya transaksi:

$$
\begin{array}{r}
\text { Kredit yang diberikan } \\
\text { Kas/Rekening }
\end{array} \quad \mathrm{xxx} \quad \mathrm{xxx}
$$

Pendapatan bunga diakui secara akrual, kecuali pendapatan bunga atas kredit yang diklasifikasi sebagai non performing. Pendapatan bunga non performing diakui secara kas atau pada saat pendapatan tersebut telah diterima. Pendapatan bunga atas kredit yang diklasifikasi sebagai non performing yang belum diterima dilaporkan sebagai pendapatan bunga dalam penyelesaian dalam laporan komitmen dan kontijensi sebagai tagihan kontijensi.

\section{Pendapatan Bunga Pada Bank Perkreditan Rakyat PRISMADANA}

Jurnal yang dibuat pada saat timbulnya biaya transaksi:

Kredit yang diberikan-biaya transaksi

Kas/Rekening

Apabila tidak terjadi persetujuan kredit maka jurnal yang dibuat adalah sbb:

Beban operasional-beban pemasaran

Kredit yang diberikan-biaya transaksi
XXX

XXX 
Pada saat kredit telah mendapatkan persetujuan dari perusahaan jurnal yang dibuat adalah sbb:

Rekening lawan-fasilitas kredit

yang belum digunakan $\quad \mathrm{xxx}$

Kewajiban komitmen-fasilitas kredit
yang belum digunakan

Jurnal yang dibuat pada saat penarikan kredit:

Kredit yang diberikan-baki debet

Kas/rekening

Kredit yang diberikan-provisi

Kewajiban komitmen-fasilitas kredit

yang belum digunakan

Rekening lawan-fasilitas kredit

yang belum digunakan

XXX

$\mathrm{XXX}$

$\mathrm{XXX}$

Kredit performing:

a) Pada saat pengakuan bunga (akrual):

Pendapatan bunga yang akan diterima

XXX

Pendapatan bunga kredit

XXX

XXX

b) Pada saat amortisasi biaya transaksi dan provisi: Pendapatan bunga

Kredit yang diberikan-biaya transaksi

Kredit yang diberikan-provisi

Pendapatan bunga

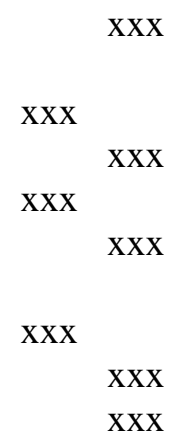

c) Pada saat menerima pembayaran:

Kas/rekening

Pendapatan bunga yang akan diterima

Kredit yang diberikan

Kredit non performing:

a) Pada saat kredit menjadi non performing

-Koreksi atas pengakuan bunga/pendapatan bunga

Pendapatan bunga(koreksi atas pendapatan bunga

yang diakui pada periode berjalan)

Pendapatan bunga(koreksi atas pendapatan bunga

yang diakui pada periode sebelumnnya)

Pendapatan bunga yang akan diterima

XXX

$\operatorname{XXX}$

$\mathrm{XXX}$

-Pendapatan bunga akrual dan pengakuan bunga akrual selanjuttnya dicatat dalam rekening administratif (off balanced sheet) :

Tagihan kontinjensi-pendapatan bunga kredit dalam penyelesaian

Rekening lawan-tagihan kontinjensi

$\operatorname{xxx}$

$\mathrm{XXX}$

b) Pada saat amortisasi biaya transaksi dan provisi:

Pendapatan bunga

Kredit yang diberikan-biaya transaksi

XXX

$\mathrm{xxx}$

Kredit yang diberikan-provisi

Pendapatan bunga

$\operatorname{xxx}$

$\mathrm{xxx}$

c) Pada saat menerima pembayaran

1) Apabila pokok kredit masih mempunyai saldo:

Kas/rekening

Kredit yang diberikan

2) Apabila pokok kredit sudah tidak bersaldo:

Kas/rekening

Pendapatan bunga

$\operatorname{XXX}$

$\mathrm{XXX}$

$\operatorname{XXX}$

$\mathrm{xxx}$

3) Pengurangan catatan extracomptable atau rekening memorial sebagai berikut:

Rekening lawan-tagihan kontinjensi(pendapatan $\mathrm{xxx}$ 
bunga kredit dalam penyelesaian)

Tagihan kontinjensi-pendapatan bunga kredit

XXX

dalam penyelesaian

Hasil akhir dari proses akuntansi adalah diterbitkannya laporan keuangan yang berakhir setiap satu periode akuntansi PT.BPR PRISMADANA MANADO, dalam menyajikan laporan keuangannya mengacu pada standar akuntansi keuangan khususnya PSAK No.50 mengenai penyajian laporan keuangan.

\section{PEMBAHASAN}

Hasil penelitian yang dilakukan di PT.BPR PRISMA DANA, menunjukkan pengakuan pendapatan bunga kredit menggunakan metode accrual basis atau lebih mengarah pada konsep realisasi. Kecuali untuk pendapatan bunga atas pinjaman yang diberikan yang diklasifikasikan bermasalah (nonperforming) diakui pada saat pendapatan itu diterima (cash basis). Pendapatan bunga menggunakan system bunga efektif anuitas yang dihitung berdasarkan pokok hutang tersisa. Angsuran yang diminta setiap bulan tidak berubah, yang berubah adalah pokok cicilan yang bergerak naik serta bunga yg bergerak turun sesuai dengan lamanya jangka waktu pinjaman.

Pendapatan bunga menggunakan system bunga efektif anuitas yang dihitung berdasarkan pokok hutang tersisa. Angsuran yang diminta setiap bulan tidak berubah, yang berubah adalah pokok cicilan yang bergerak naik serta bunga yg bergerak turun sesuai dengan lamanya jangka waktu pinjaman

\section{Analisis Penerapan Pedoman Akuntansi BPR (PA-BPR) pada PT.BPR PRISMADANA}

PT.BPR Prismadana Manado melakukan pengakuan pendapatan bunga atas pemberian kredit modal kerja berdasarkan pedoman akuntansi Bank Perkreditan Rakyat (PA-BPR).

Tabel 4.2 Perbandingan PA-BPR Dengan Perlakuan Pada Perusahaan Tentang Pengakuan Pendapatan Bunga Kredit

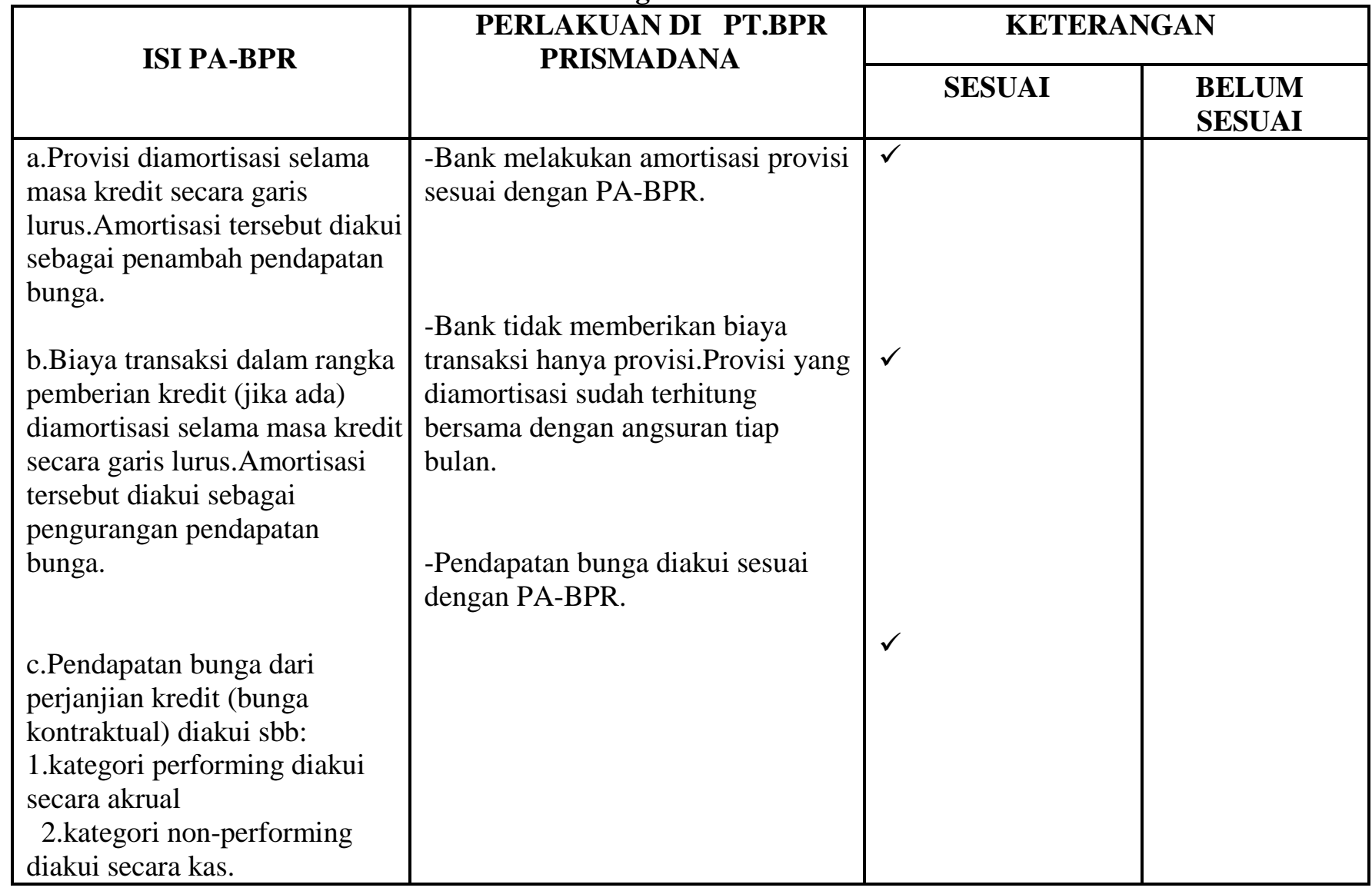




\section{Analisis Perbandingan antara PSAK No.23 Dengan Perlakuan di Perusahaan tentang Pengakuan Pendapatan Bunga Kredit}

Tabel 4.4 Perbandingan antara PSAK NO.23 dengan Perlakuan di Perusahaan tentang Pengakuan pendapatan bunga kredit.

\begin{tabular}{|c|c|c|c|}
\hline \multirow{2}{*}{ ISI PSAK NO.23 } & \multirow{2}{*}{$\begin{array}{c}\text { PERLAKUAN DI } \\
\text { PT.BPR } \\
\text { PRISMADANA }\end{array}$} & \multicolumn{2}{|c|}{ KETERANGAN } \\
\hline & & SESUAI & BELUM SESUAI \\
\hline $\begin{array}{l}\text {-Pendapatan bunga kredit } \\
\text { diakui menggunakan metode } \\
\text { suku bunga ekektif }\end{array}$ & $\begin{array}{l}\text {-perusahaan } \\
\text { mengakui pendapatan } \\
\text { bunga kredit } \\
\text { menggunakan suku } \\
\text { bunga efektif. }\end{array}$ & $\checkmark$ & \\
\hline $\begin{array}{l}\text {-Jika bunga kredit yang } \\
\text { belum dibayar telah diakru } \\
\text { sebelum pembelian investasi } \\
\text { yang berbunga,maka } \\
\text { penerimaan bunga kemudian } \\
\text { dialokasikan antaran periode } \\
\text { sebelum pembelian dan } \\
\text { sesudah pembelian, hanya } \\
\text { bagian setelah pembelian } \\
\text { yang diakui sebagai } \\
\text { pendapatan }\end{array}$ & $\begin{array}{l}\text {-perusahaan } \\
\text { mengakui pendapatan } \\
\text { bunga perjanjian } \\
\text { kredit (bunga } \\
\text { kontraktual) sbb: } \\
\text { 1.kategori } \\
\text { performing diakui } \\
\text { secara akrual } \\
\text { 2.kategori non- } \\
\text { performing diakui } \\
\text { secara kas. }\end{array}$ & $\checkmark$ & \\
\hline
\end{tabular}

Demikian hasil penelitian dan pembahasan yang dilakukan oleh penulis mengenai Pengakuan Pendapatan Bunga atas pemberiam kredit modal kerja yang dibandingkan dengan Pedoman Akuntansi Bank Perkreditan Rakyat (PA-BPR) dan Pernyataan Standar Akuntansi Keuangan (PSAK) nomor 23 tentang Pengakuan Pendapatan pada PT. BPR PRISMA DANA MANADO.

\section{KESIMPULAN DAN SARAN}

\section{Kesimpulan}

Berdasarkan hasil penelitian dan pembahasan yang dikemukakan pada bab sebelumnya maka dapat disimpulkan:

1. Metode pengakuan pendapatan bunga pada PT.BPR Prismadana Manado sudah sesuai dengan Pernyataan Standar Akuntansi Keuangan (PSAK) No.23 dan Pedoman Akuntansi BPR (PA-BPR). Dimana pendapatan bunga diakui secara akrual.

2. PT. BPR Prismadana Manado menggunakan metode dasar akrual menuju modifikasi dasar kas pada saat pengeluaran pendapatan bunga, karena sebelum akhir bulan bunga masih dianggap sebagai bunga yang masih harus diterima, pada saat akhir bulan bunga tersebut baru diakui sebagai hasil atau pendapatan bunga bagi bank.

3. Pendapatan diakui dalam laporan laba rugi dan pengakuan terjadi bersamaan dengan pengakuan kenaikan aktiva atau penurunan bunga bagi bank.

4. Beban bunga diakui secara akrual

5. Laporan keuangan sudah sesuai dengan PSAK No. 50 tentang penyajian laporan keuangan.

\section{Saran}

PT. BPR Prismadana wajib mempertahankan metode pengakuan pendapatan yang sedang digunakan dan diterapkan secara konsisten pada setiap periode akuntansi agar informasi keuangan mengenai pendapatan bunga kredit disajikan secara wajar dan proporsional serta menghasilkan penandingan yang lebih baik antara pendapatan dan beban selama periode akuntansi dan menghasilkan laporan keuangan yang lebih akurat dalam mencerminkan posisi keuangan dan hasil suatu operasi. Selain itu cara perhitungan pendapatan bunga kredit kiranya bisa dipertahankan mengingat baik nasabah dan perusahaan tidak merasa dirugikan. 


\section{DAFTAR PUSTAKA}

Horngren, C.T., Harrison Jr, W.T.2007. accounting: Pearson International Edition.

Harahap, Sofyan Syafri, 2011. Teori Akuntansi, PT. Raja Grafindo Persada 2011,Jakarta

Hasibuan, Malayu, 2011. Dasar-dasar Perbankan, Sinar Grafika Offset, Jakarta

Hery, (2013), Akuntansi Dasar, Penerbit PT Gramedia Pustaka Utama, Jakarta.

Ismail,2009. Akuntansi Bank, Teori dan Aplikasi dalam Rupiah, Kencana 2009, Jakarta.

Kieso, Donald E, and Jerry J.Weygant. Intermediate Accounting, Sixth Edition, John Wiley and Sons,1989, New York

Kasmir, 2011. Dasar-dasar perbankan ,PT. Raja Grafindo Persada 2011, Jakarta

Kuncoro, Mudrajad,2003. Metode Riset Untuk Bisnis dan Ekonomi, Erlangga Jakarta

Pernyataan Standar Akuntansi Keuangan, No.23, Pendapatan, Revisi 2010

Pernyataan Standar Akuntansi Keuangan, No.50, Penyajian, Revisi 2014

Suhardjono, Indra Bastian, 2006. Akuntansi Perbankan, Salemba Empat Jakarta

Soemarso S.R, 2005, Akuntansi Suatu Pengantar, Buku Dua. Salemba Empat Jakarta

Ramly Faud dan Rustan D.M, 2005. Akuntansi Perbankan, Erlangga Jakarta

Yadiati, Winwin,. Wahyudi,Ilham. 2006. Pengantar Akuntansi. Ed. Revisi. Jakarta 